\section{Science journalists become activists}

Science journalists must play an active role in development, and not be mere transmitters of technical information. This argument for a marked departure from the journalists' traditional 'neutral' role came not from an outside body, but from science journalists themselves, meeting last week in Laxenburg, near Vienna. The conference, part of the run-up to UNCSTD in Vienna in August, was organised by the European Union of Associations of Science Journalists.

There is a north/south imbalance in science and technology that is "increasing the gap between rich and poor", the journalists argue in their 'Laxenburg Declaration'. This is exacerbated by an information imbalance: "information is dominated by the industrialised countries".

The role of science journalists, then, is to help redress these imbalances. But they stressed that this is not simply a passive act-"the science journalist is a partner in development". In particular, one role of the science journalist is to "strengthen the bargaining position of developing nations in negotiations with suppliers of technology"multinationals and foreign governments.

This new active posture carries risks. The declaration warns that "in the exercise of their role to aid development, science journalists may offend governments, media owners, and other powerful forces. In both the industrialised and non-industrialised world, they face punishment and jail". The journalists included the reference to industrialised nations in the latter sentence in recognition of the trial of science journalist Duncan Campbell in Britain last year.

Naturally, the journalists supported freedom of information and freedom of the press. But they pointed out that in the context of science this means that "i.ee access to information in government and private research institutions should be guaranteed. Special attention should be given to the access to information from industrial and military research, in particular from companies and agencies operating on a worldwide basis".

Underlying the declaration was an acceptance of a view gaining increasing currency in the Third World-that the industrialised nations, through their aid policies and their multinational companies, are trying to impose particular patterns of technology on the developing world. It is up to the developing countries to decide which technologies are appropriate and, indeed, whether to adopt so-called appropriate technologies at all.

\title{
Mössbauer's lab destroyed by fire
}

Professor Rudolf Mössbauer, Nobel prizewinner for physics in 1961, has lost his entire laboratory in an intense fire which raged in the Technical University of Munich in Garching last Saturday morning. According to first estimates, the fire began in the middle of an open corridor in the laboratory, setting light to a small theoretical physics library above. Arson is suspected, and the whole Garching site of the university has been closed off and is under strict security.

The entire building containing Mössbauer's laboratory was destroyed, taking with it a laser physics and low temperature laboratory of Professor Helmut Kinder.

Some of the equipment may be salvageable, but the damage has been aggravated by corrosion. The fabric of the building contained large amounts of polyvinylchloride, which with the heat of the fire and contact with the water used to extinguish the blaze, produced hydrochloric acid. This has corroded equipment which was otherwise undamaged. Meanwhile the staff of other departments on the site are rallying round to offer room to the disestablished researchers. However it will take at least a year-and maybe several-to rebuild the laboratory to its previous condition, and the experiments that were in progress have been lost.

The extent of the damage has been estimated between 5 and 20 million DM. The equipment and laboratory were insured.

If the fire was the work of an arsonist-and that is by no means established-speculation will begin on possible motives. Professor Mössbauer is known to be a man of firm and vocal right wing views, and a political motive would not be entirely out of the question.

\section{Oil giants exaggerated Harrisburg-Izvestiya}

"SLIGHT unpleasant consequences" was how academician Anatolii P. Aleksandrov, President of the Soviet Academy of Sciences, described the outcome of the Harrisburg nuclear accident.

Commenting in the paper Izvestiya on future world prospects for nuclear power, Aleksandrov maintained that the media coverage of Harrisburg had been "exceptionally over-stated". This, he implied, was due to the oil interests which "control the energy production of practically all the capitalist and many of the developing countries" and whose drive for maximum profits "is opposed to the interests both of the countries which possess petroleum, but also often to the interests of the petroleum consumer countries".

The Soviet Union has a major commitment to fast-breeder power generation, and the Western alarms which followed Harrisburg caused one notable change in policy. Until now, Soviet officials have been reluctant to admit to any accidents at their nuclear power stations. A few days after Aleksandrov's article, however, Peter Neporozhnii, who is the Soviet Minister of Power and Electrification, admitted to western journalists, that the Soviet Union had had a few nuclear mishaps. No details were given, but it was assumed that he referred first and foremost to the Shevchenko semi-pilot fast breeder, where in 1973 there was a "conventional" explosion when a ruptured heat exchanger brought hot sodium and water into contact.

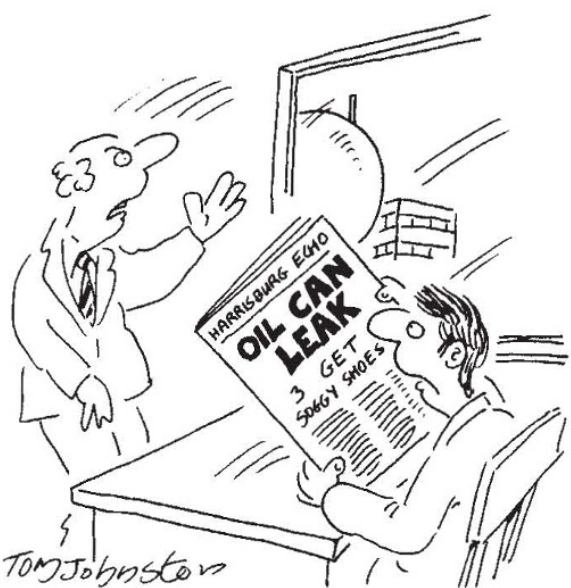

"Well I'd hardly call it getting our own back!"

Meanwhile Czechoslovakia continues to deny the two nuclear accidents which the Chartists allege took place in January 1967 and February 1977. They have, however, in the wake of Harrisburg, announced considerable improvements in their nuclear safety programme. Speaking on the Englishlanguage service of Prague radio, $\mathrm{Z}$. Dlouhy, the head of the Radiation Safety Department of the Nuclear Research Institute at Rezh, said new legislation "places the country among the most advanced in the world in this respect". Prospective sites for power stations, he said, are evaluated from the point of view of numerous external effects, which range from average precipitation and wind patterns to seismic activity and the possibility of aircraft crashing on the plant. 